\title{
INSTITUTIONAL FRAMEWORK FOR ACCIDENT MANAGEMENT: A CASE STUDY IN FIRE RESCUE BRIGADES PRACTICE
}

\author{
UDC 614.8
}

\author{
Marijola Božović ${ }^{1}$, Emina Mihajlović ${ }^{2}$, \\ Ivana Ilić-Krstić , Snežana Živković \\ ${ }^{1}$ Higher Technical Professional School in Zvečan, Serbia \\ ${ }^{2}$ Faculty of Occupational Safety in Niš, University of Niš, Serbia
}

\begin{abstract}
Managing the risk of accidents for the purpose of ensuring occupational and environmental safety involves a number of activities, measures, and programs to be taken before, during, and after an accident in order to avoid it, reduce its impact, and mitigate its effects, respectively. A company or another legal entity is obligated to devise an accident protection plan and to adhere to it when taking measures of accident prevention and minimization of the impact on human life and health, property, and the environment. The structure of such a plan is presented along with the legal framework for accident management.

This paper contains an insight about opinions of the members of fire rescue brigades regarding various aspects of emergencies in the context of accident management in general. A total number of 45 respondents participated in the study. Findings indicate that almost all respondents believe that their skills and abilities are applicable in the intervention phase and less than a half believe that their skills are applicable in prevention phase, while two-thirds of respondents stated that they have support for further education and upgrading in their organizations.
\end{abstract}

Key words: emergencies, risk management, fire rescuer, accident prevention

\section{INTRODUCTION}

Hazardous materials in production, use, transport, marketing, storage, and disposal are handled in a certain way so as not to endanger human life and health or pollute the environment, which requires the implementation of accident protection measures and other measures established by the law. Accident protection includes planning, organization, and

Received November 28, 2018 / Accepted December 28, 2018

Corresponding author: Snežana Živković

University of Niš, Faculty of Occupational Safety in Niš, Čarnojevića 10a, 18000 Niš, Serbia

E-mail: snezana.zivkovic@znrfak.ni.ac.rs 
implementation of preventive and other measures of hazardous material management based on hazard analysis, all for the purpose of reducing the risk of accidents. The consequences of accidents may include substantial losses, damage, and other negative factors for people, property, and the environment. Accident management goals are to reduce or avoid potential hazard losses, to provide prompt and proper aid for victims of a disaster, and to achieve a fast and effective recovery. The accomplishment of the first of these goals requires measures of prevention, mitigation, and minimization of the accident effects.

Modern safety challenges, risks and threats have increased the interest for problems of occupational and environmental safety. Members of fire rescue brigades, as one of the subjects of an integrated system of safety, protection and rescuing of people, assets and environment in general, are often working in the conditions of high risk [2]. The profession of firemen-rescuers is very demanding both from a psychological and physical aspect, where the risk of exposure to hazards is usually high. During the performance of working activities, the firemen are regularly exposed to very hazardous and traumatic occurrences that can lead to situation that involves the loss of life, physical injury, coping with death and injuries of colleagues [15].

\subsection{International frameworks of accident management initiative}

To increase protection against major accidents, a series of documents were enacted in the EU in the mid-1990s and early 2000s, whose requirements were considerably different when compared to the previously prevalent understanding of risk management. For instance, the Convention on the Transboundary Effects of Industrial Accidents [4] governs the procedures of the convention signees in cases of 'transboundary effects'. It is more detailed than the Seveso I Directive [13] regarding the development of procedures for chemical accident control, which are acceptable as the basic methodology for risk assessment.

Directive $96 / 82 / E C$ is aimed toward prevention of major accidents involving hazardous materials and toward mitigation of human and environmental impact by providing high levels of protection in a consistent and efficient manner [14].

APELL - Awareness and Preparedness for Emergencies at Local Level is a publication of a program by the UNEP IE/PAC. The strategic approach of APELL is to identify and raise awareness of the presence of risk in industrialized communities, to initiate measures for risk reduction and mitigation, and to create a coordinative development of preparedness between the industry, the local government, and the population [1].

TransAPELL - Guidance for Dangerous Goods Transport Emergency Planning in a Local Community is a publication of a program by the UNEP IE/PAC expands the APELL instructions for risks pertaining to stationary facilities with the risks originating from the transport and distribution of hazardous merchandise [16]. Planning in terms of transport risks is as necessary as the planning in terms of risks in stationary facilities, but even more complex. The program has two main goals: (1) to create and/or raise the awareness of a community about the potential hazards related to hazardous material manufacture, handling, and use, and about the steps taken by the authorities and the industry to protect the community against such hazards; (2) to develop hazard response plans in conjunction with the local communities. 


\subsection{National accident management framework}

Definition of elements for risk management in Serbia began in 1994, with the introduction of Hazard Assessment Methodology, provided within the document Rules on the Methodology for Assessing Chemical Accident and Environmental Pollution Hazards, and Preparation and Recovery Measures [12]. The Rules were adopted according to the Directive 82/501/EEC (Seveso I), so it clearly does not include Directive 96/82/EC, Directive 96/61/EC [5], UN/ECE Convention on the Transboundary Effects of Industrial Accidents, UN/ECE Convention on Environmental Impact Assessment in a Transboundary Context [3], and the Protocol on Strategic Environmental Assessment to the Convention on Environmental Impact Assessment in a Transboundary Context [10]. The enactment of the Law on Environmental Protection [8], the Law on Integrated Prevention and Control of Environmental Pollution [9], and the Law on Environmental Impact Assessment [7] has initiated a new phase in the development of risk assessment methodology.

According to the Law on Environmental Protection, an accident is a sudden and uncontrolled event or a series of events resulting from uncontrolled release, discharge, or spillage of hazardous materials during their manufacture, marketing, use, transport, processing, storage, disposal, and inadequate long-term preservation.

According to the EU Seveso II Directive, a major accident is an occurrence such as a major pollutant emission into the environemnt, fire, or explosion resulting from uncontrolled developments in the course of an industrial activity, and leading to serious danger to human health and/or the environment, immediate or delayed, inside or outside the establishment, and involving one or more dangerous substances.

Based on the Law on Emergencies [6], a Regulation on the Content and the Manner of Devising Emergency Safety and Rescue Plans was enacted. The Regulation governs the content and the procedure of creating the Emergency Safety and Rescue Plan on the national level, the level of state administration, autonomous provinces, local self-government units, companies and other legal entities, and other organizations.

Companies and other legal entities dealing in manufacture, storage, and transport of hazardous materials and the management of buildings potentially exposed to terrorist attacks are obligated to create a document Accident Protection Plan, which is an integral part of the Safety and Rescue Plan. The Accident Protection Plan is devised according to the Rules on the Manner of Devising and the Content of Accident Protection Plans [11].

Pursuant to the Law on Emergencies, the Accident Protection Plan governs the following aspects: organisation and procedures of notification and engagement of accident response authorities; situational assessment and decision making; risk reduction measures for employees at high-risk workplaces involved in accidents; early warning and notification of state authorities and local self-government units about the accident, followed by public announcements, including the aid measures employed by those authorities during their protection plan implementation; organization of authorities and employees in the implementation of safety and rescue measures and environmental protection in the event of accident; organization of informing the public; organization of work continuation and accident recovery. 


\section{Structure of the ACCIDENT Protection Plan}

The structure of the Accident Protection Plan is the following:

1. Hazard assessment;

2. Accident response measures;

- Engagement of accident response authorities;

- Safety and rescue measures;

- Accident recovery measures;

3. Informing the public.

Hazard assessment is performed to establish the danger to human life and health and the vulnerability of buildings and the environment from the effects of accidents caused by activities involving hazardous materials or by terrorist activities. It contains the general information about the company or another legal entity, hazard identification, prevention measures, and assets.

General information about the company or another legal entity is obtained through data collection and it includes the following: name and location of legal entity; data on responsible person(s); data on hazardous materials; properties of hazardous materials generated during accidents; listing of hazardous materials; used technologies; data on the characteristics of facilities, devices, and equipment; data on the characteristics of buildings, devices, and equipment in terms of vulnerability to terrorist activity; and characteristics of the location and its surrounding.

Hazard identification involves the identification of buildings and critical points, i.e. locations in a process or a facility that constitute the weakest points or potential sources of accident hazards. The identification stage is particularly focused on analyzing the human factor as a potential cause of accident.

Representation of a possible turn of events, or a scenario, involves the analysis of potential causes, the scope, and the effects on humans, animals, the environment, and property. A scenario has to acknowledge the complexity and purpose of buildings or facilities, the complexity and danger of manufacturing processes, the level of hazardous activities by the company or another legal entity, and the possible consequences.

A vulnerability analysis is aimed at identifying and listing the following parameters: the total number of employees in a facility or a complex; jobs and the number of employees currently performing their job tasks in a facility or a complex; the number of people who are expected to be in a facility/building in predicted accident areas (it is necessary to represent the distribution of employees graphically over a layout plan of the facility/complex/building); the number of people at least $1 \mathrm{~km}$ away from the complex/building. The possible accident level is determined based on the predicted scenario and vulnerability analysis, and is expressed by a five-point scale.

Preventive measures are taken in order to prevent or reduce the probability of an accident and to mitigate its effects. Preventive measures comprise the following: measures planned or implemented by spatial planning, design, and construction of the facility or complex building; measures planned or implemented by the selection of manufacturing technology, technological equipment, process management equipment, and other technical equipment; measures planned by the selection of technical and technological solutions that provide safer transport of hazardous materials; measures providing quality and timely maintenance of the technical and technological aspects of a building/facility, the level of knowledge, and the level of work and technological discipline; measures intended to 
maintain passageways and hallways in buildings/facilities; measures planned for the safety system: supervision, security and safety system management, and hazard detection and identification; measures planned by the organization of training and education of human resources for accident response; measures planned by the creation and verification of planning documentation for accident response.

Assets for safety and rescue and for mitigation and elimination of accident effects - this portion pertains to assets, their capacities, and the need to implement safety and rescue measures and accident effect mitigation and elimination. It comprises the available human resources, available material assets and safety and rescue equipment, and assessment of the suitability of human resources and material assets to provide assistance.

Accident response measures comprise the following:

- engagement of accident response authorities defines the procedures and measures that elaborate the activities and procedures of authorized bodies and organizations (human and material resources) and their preparedness to perform safety and rescue tasks;

- safety and rescue measures define the procedures and measures to be taken in order to mitigate the effects of accidents;

- accident recovery measures are aimed at mitigating the effects, organizing postaccident monitoring and recovery, and creating conditions for restoring life and work at the location of the accident.

Informing the public involves defining and elaborating procedures of notifying and informing the public about the hazards, measures taken to prevent the accident from spreading, safety and rescue measures, and accident recovery measures, or more specifically: general information about the nature of the hazard from hazardous materials (with an emphasis on the main hazardous properties) potentially affecting humans, animals, the environment, and property; measures and manner of timely notification of employees and the general population about the accident location and effects; a person responsible for communicating with the public; measures and activities taken within the company or another legal entity in order to prevent the accident effects from spreading further or to eliminate them.

\section{MATERIALS AND METHODS}

For the purpose of this study, members of fire rescue brigades were interviewed. The total number of respondents in the sample was 45 , and the percentages shown in the tables are calculated in relation to this number.

The structure of the sample was first verified in terms of the working status of the respondents and the sociodemographic variables examined. The results are shown in the tables $1-6$.

Table 1 Structure of the sample in relation to the years

\begin{tabular}{lcc}
\hline Age of respondents & $\begin{array}{c}\text { Number of } \\
\text { respondents }\end{array}$ & Percentage \\
\hline 18-30 years & 6 & 13.3 \\
31-45 years & 29 & 64.4 \\
46 and over & 10 & 22.2 \\
\hline
\end{tabular}


Table 2 Structure of the sample in relation to the level of education

\begin{tabular}{lcc}
\hline Level of education & $\begin{array}{c}\text { Number of } \\
\text { respondents }\end{array}$ & Percentage \\
\hline High school & 35 & 77.8 \\
Higher school & 7 & 15.6 \\
Master, specialization, doctorate & 3 & 6.7 \\
\hline
\end{tabular}

Table 3 Structure of the sample in relation to the nature of education

\begin{tabular}{lcc}
\hline Nature of education & $\begin{array}{c}\text { Number of } \\
\text { respondents }\end{array}$ & Percentage \\
\hline Socially-humanistic & 10 & 22.2 \\
Natural-mathematical & 5 & 11.1 \\
Technical-technological & 30 & 66.7 \\
\hline
\end{tabular}

Table 4 Structure of the sample in relation to whether they are members of a professional or voluntary fire brigade

\begin{tabular}{lcc}
\hline Type of unit & $\begin{array}{c}\text { Number of } \\
\text { respondents }\end{array}$ & Percentage \\
\hline Professional Fire Unit & 45 & 100.0 \\
Voluntary Fire Fighting Society & 0 & 0.0 \\
\hline
\end{tabular}

Table 5 Structure of the sample in relation to the institution / formation to which the firefighter-rescue unit of the respondent belongs

\begin{tabular}{lcc}
\hline Formation & $\begin{array}{c}\text { Number of } \\
\text { respondents }\end{array}$ & Percentage \\
\hline Fire Department Rescue Unit & 1 & 2.2 \\
Firefighting unit of the Ministry of Defense and Army of Serbia & 0 & 0.0 \\
Fire and Rescue Unit of Local Self-Government & 44 & 97.8 \\
Firefighting-rescue unit of legal entity from I category of fire risk & 0 & 0.0 \\
\hline
\end{tabular}

Table 6 Structure of the sample in relation to whether the respondent is in the managerial position or not

\begin{tabular}{lcc}
\hline Leading place? & $\begin{array}{c}\text { Number of } \\
\text { respondents }\end{array}$ & Percentage \\
\hline Yes & 14 & 31.1 \\
No & 31 & 68.9 \\
\hline
\end{tabular}

From the tables 1-6 it can be seen that all respondents are members of professional fire brigades, all but one of them are members of local self-government units. Something more than three quarters of respondents have secondary education, while higher levels of education have only 10 respondents. When asked about types of education, two thirds of respondents claim to have technical and technological education, while a total of 15 respondents state that they have a socio-humanistic or natural-mathematical education. In terms of age, the sample is diverse, with respondents in all three categories, although the 
highest percentage of subjects is in the category of 31 to 45 years. Of the examined numbers, slightly less than a third of respondents are in managerial positions. Bearing this in mind, when conducting comparisons by groups of comparisons, they will not be carried out against the type of firefighting unit, as all members of professional fire brigades, as well as in relation to the formation of which the fire brigade of the respondents belongs, because they are all but one member of the local self-government units. When it comes to education, having in mind the distribution of respondents by category, comparisons will be made between respondents with secondary education and those with higher levels of education. When it comes to the nature of education, the comparison will be done between the respondents with technical and technological education and others.

The descriptive tables below (tables 7-11) show the descriptive statistical measures frequencies, percentages, arithmetic meanings, standard deviations, respondents' answers to other questions from the survey.

\section{RESULTS AND DISCUSSION}

When it comes to the frequency of various types of outlandish situations (table 7), it can be seen that respondents, on the average, identify the extraordinary situations of natural and technical-technological character as clearly the most common types of situations. Extraordinary situations that result from terrorist actions and violence are listed as rare, while as most convincingly they state the extraordinary situation of an ecological character.

When it comes to the frequency of respondents' answers to questions about the impact of specific territorial and safety conditions in which they live on safety in the work and living environment, the respondents of all 45 respondents stated that these conditions have such an impact.

Table 7 Respondents' statements about the frequency of various types of emergencies

\begin{tabular}{lcccc}
\hline Type of emergency & $\begin{array}{c}\text { Arithmetic } \\
\text { mean }\end{array}$ & $\begin{array}{c}\text { Standard } \\
\text { deviation }\end{array}$ & Minimum Maximum \\
\hline $\begin{array}{l}\text { Natural character } \\
\text { (earthquakes, floods, landslides, forest fires) }\end{array}$ & 3.69 & 2.494 & 0 & 10 \\
$\begin{array}{l}\text { Technical-technological character } \\
\text { (traffic accidents, fires on electrical installations, }\end{array}$ & 3.98 & 2.547 & 0 & 10 \\
explosions, industrial disasters) & & & & \\
$\begin{array}{l}\text { Ecological character (environmental degradation) } \\
\text { Terrorist actions, consequences of violence }\end{array}$ & 0.42 & 0.587 & 0 & 2 \\
\hline
\end{tabular}

Distribution of respondents' responses to questions about the importance of respondents' skills for implementation in the emergency situations and emergency intervention are given in the table 8 . 
Table 8 Distribution of respondents' answers to questions about the extent to which the skills and abilities of the respondents themselves can be applied at the stage of prevention or intervention in an emergency

\begin{tabular}{lcc}
\hline Distribution & $\begin{array}{c}\text { Number of } \\
\text { respondents }\end{array}$ & Percentage \\
\hline In the prevention phase? & 18 & 40 \\
Totally & 27 & 60 \\
Partially & & \\
At the intervention stage? & 43 & 95.6 \\
Completely & 2 & 4.4 \\
Partially & & \\
\hline
\end{tabular}

From the table 8 it can be seen that almost all respondents consider their skills and abilities to be applicable at the intervention stage, but less than half think that their skills are applicable at the prevention phase.

Table 9 Distribution of respondents' answers to questions about readiness to acquire new knowledge, skills and competences in the field of work and life safety, about preprepared methods and places of acquiring these knowledge, and about previous experience with emergency training

\begin{tabular}{lrr}
\hline Distribution & $\begin{array}{c}\text { Number of } \\
\text { respondents }\end{array}$ & Percentage \\
\hline Would you like to acquire new or expand existing knowledge, skills & & \\
and capabilities related to work and environmental safety ? & 44 & 97.8 \\
$\quad$ Yes & 1 & 2.2 \\
$\quad$ No & & \\
How would you like to gain certain skills for work and environment & 11 & 24.4 \\
protection, including safety and health at work? & 2 & 4.4 \\
$\quad$ Lectures in classical teaching & 1 & 2.2 \\
$\quad$ In discusional groups & 4 & 8.9 \\
$\quad$ Self-education & 28 & 62.2 \\
$\quad$ Public lectures, stands & 0 & 0.0 \\
$\quad$ Seminars, courses and workshops & & \\
$\quad$ Through means of public information & 19 & 42.2 \\
Where would you like to acquire the knowledge and skills & 1 & 2.2 \\
necessary to perform work tasks? & 0 & 0.0 \\
$\quad$ In the working organization & 25 & 55.6 \\
In the school institution & & \\
At home & & \\
In different educational centers & 21 & 46.7 \\
So far, did you attend trainings, courses and seminars related to & 11 & 24.4 \\
training procedures and checking the emergency plan? & 13 & 28.9 \\
$\quad$ Yes & & \\
Sometimes & & \\
$\quad$ No & &
\end{tabular}


Data displayed in the table 9 show that almost all respondents express their willingness to acquire new or expand the knowledge, skills and capabilities in the field of work and environment safety. As the main ways of acquiring these knowledge, they see seminars, courses and workshops, as well as classical teaching, and as places where they would like to acquire these skills almost exclusively see different educational centers and work organization. A little less than a third of the respondents state that they have not attended trainings, courses and seminars related to the conduct of procedures and checking the emergency plan.

When asked about the type of training they have been attending so far, out of 45 respondents, 24 answered the question with 'of whatever type'. Out of the 24 respondents, 15 of them answer only Basic (basic course), while 5 other respondents state the Basic, but with additional specifications - first aid, auto accident, basic course of command, 3 respondents cite a rescue program from ruins and car accidents, while one respondent mentions training in the workplace as a type of training.

Distribution of respondents' responses to the question of the quality of cooperation with the competent authorities and other services that play an important role in the protection of the working and environment are given in the table 10 .

Table 10 Distribution of respondents' responses to the question of the quality of cooperation with the competent authorities and other services that play a significant role in the protection of the environment

\begin{tabular}{lcc}
\hline $\begin{array}{l}\text { What is the cooperation with the competent authorities and } \\
\text { other services that play an important role in the protection } \\
\text { of the working and environment? }\end{array}$ & $\begin{array}{c}\text { Number of } \\
\text { respondents }\end{array}$ & Percentage \\
\hline Good & 17 & 37.8 \\
Mostly good & 21 & 46.7 \\
Poor & 7 & 15.6 \\
\hline
\end{tabular}

From the table 10 we see that more than five-sixth of the respondents, that is, a very large majority of respondents, assess the cooperation with the competent authorities and other services in the protection of the working and environment as good or mostly good, while only 7 respondents are rated as poor.

Then the respondents were asked to evaluate the degree of spontaneity they encounter in their organization to provide support in further education and training for better safety of the work and environment, on factors that are an obstacle to such a practice, topics that should be covered by educational programs in this field, and ways in which better preparedness could be achieved for an adequate and effective response in emergency situations. Distribution of respondents' answers to these questions are shown in the table 11.

The percentages of the answer to the question about the reasons for the guidelines are in relation to the total sample, as the respondents had the opportunity to round up more responses in this issue. 
Table 11 Distribution of respondents' responses to questions about the level of readiness they encounter in their organization to provide support in further education and training for better safety of work and environment and on factors that impede such practices

\begin{tabular}{lrr}
\hline Distribution & $\begin{array}{c}\text { Number of } \\
\text { respondents }\end{array}$ & \\
\hline Whether in your organization you are ready to receive support in further & \\
education and training for better safety of your work and environment ? & 29 & 64.4 \\
Yes & 15 & 33.3 \\
No & 1 & 2.2 \\
Did not give an answer & 17 & 37.8 \\
Which of the following reasons pose an impediment to your further & 7 & 15.6 \\
education and training? & 6 \\
Poor financial situation & 4 & 13.3 \\
Absence of safety in the environment in which I live & 8.9 \\
Distance from educational centers & 1 & 2.2 \\
Untimely information about the learning opportunities that you want & \\
Unwillingness of the management to give you the opportunity for & 2 \\
your further education and training & 4.4 \\
Other reasons & & \\
\hline
\end{tabular}

\section{CONCLUSION}

Through the answers, attitudes and opinions of the respondents, it can be concluded that their answers have confirmed that almost all respondents believe that their skills and abilities are applicable in the intervention phase, but less than a half believe that their skills are applicable in prevention phase. Almost all respondents expressed readiness to acquire new or expand existing knowledge, skills and abilities from the area of safety of working and living environment. They cited seminars, courses and workshops as well as traditional lectures as the main ways for acquisition of this knowledge, and as places where they would like to accomplish this almost exclusively see different education centres and working organization.

Regarding the quality of the cooperation with the competent authorities and other services that play an important role in the protection of the working and environment, it can be concluded that almost over one-third of the repondents considers such cooperation as good, while almost two-third of the respondents considers it to be mostly good and poor.

It also can be concluded that approximately two-thirds of the respondents stated that in their organization they have support for further education and upgrading, while just over one-third does not feel such support. When it comes to factors that represent the obstacles for further education and upgrading, just over one-third of respondents as a reason stated poor material situation, while other frequent reasons stated are the lack of safety in the area where they live and remoteness of education centres. Four respondents as a reason stated untimely information on training opportunities, and remaining two options were circled by one respondent.

Successful resolution of issues and problems regarding the protection of working and living condition requires a strong institutional basis, which could be accomplished by strengthening of capacities, good governance, facilitated flow of information and efficient 
coordination. It is necessary to establish stronger correlations between formal, informal and other forms of learning and education in order to introduce philosophy and practice of lifelong learning, that is, ability to update and upgrade knowledge and abilities throughout life

Planning and implementation of activities and investments on all levels, which are based on the knowledge of risk and which provide the highest possible degree of protection of people and property from potential future accidents, represents a systemic response of the society to this kind of danger and enables the reduction of the risk of accident and potential major consequences. The goal of society as a whole is to use efficient methods to minimize the impact of harmful effects due to potential or real hazards, to provide timely and efficiently organized emergency response, which can proceed even after the primary effects of an accident have waned, and to work at unifying and coordinating the activities directed toward protecting human health and property.

Acknowledgement: The research presented in this paper was financed by the Ministry of Science and Technological Development of Serbia within the projects III 43014 and III 42006.

\section{REFERENCES}

1. APELL - Awareness And Preparedness For Emergencies At Local Level: A Process For Responding To Technological Accidents, United Nations Environment Programme, Paris, France, 1988.

2. Božović, M., Živković, S., Mihajlović, E. (2018). Integrated system of occupational safety and health and fire protection of the fire rescue brigades members, International journal of injury control and safety promotion, 25(2), pp. 173-179.

3. Convention on Environmental Impact Assessment in a Transboundary Context, Espoo, 1991.

4. Convention On The Transboundary Effects of Industrial Accidents, United Nations Economic Commission for Europe (UNECE), Helsinki, 1992.

5. Council Directive 96/61/EC of 24 September 1996 concerning integrated pollution prevention and control, Official Journal L 257, 10/10/1996, p. 26-40.

6. Law on Emergencies ("Official Gazette of RS", No. 111/09, 92/11 and 93/12).

7. Law on Environmental Impact Assessment ("Official Gazette of the RS", No. 135/04 and 36/2009).

8. Law on Environmental Protection ("Official Gazette of the RS", No. 135/04, 36/2009, 72/2009, 43/2011-decis. US, 14/2016, 76/2018).

9. Law on Integrated Prevention and Control of Environmental Pollution ("Official Gazette of the RS", No. 135/04 amd 25/2015).

10. Protocol on Strategic Environmental Assessment to the Convention on Environmental Impact Assessment in a Transboundary Context, United Nations Economic Commission for Europe Kiev, Ukraine, 2003.

11. Rules on the Manner of Devising and the Content of Accident Protection Plans ("Official Gazette of the RS", No. 82/2012).

12. Rules on the Methodology for Assessing Chemical Accident and Environmental Pollution Hazards, and Preparation and Recovery Measures ("Official Gazette of the RS", No. 60/94).

13. Seveso-Directive (Council Directive 82/501/EEC of 24 June 1982 on the major-accident hazards of certain industrial activities), Official Journal L 230, 05/08/1982, p. 1-18.

14. Seveso-II Directive (Council Directive 96/82/EC of 9 December 1996 on the control of major-accident hazards involving dangerous substances), Official Journal L 10, 14/1/1997, p. 13-33.

15. Smith, B.W., Ortiz, J.A., Steffen, L.E., Tooley, E.M.,Wiggins, K.T., Yeater, E.A., Montoya, J.D., Bernard, M.L. (2011). Mindfulness is associated with fewer PTSD symptoms, depressive symptoms, physical symptoms, and alcohol problems in urban firefighters, Journal of Consulting and Clinical Psychology, 79(5), pp. 613-617.

16. TransAPELL - Guidance for Dangerous Goods Transport - Emergency Planning in a Local Community, United Nations Environment Programm, UN IE/PAC Technical Report, Paris, France, 2000. 


\section{INSTITUCIONALNI OKVIR ZA UPRAVLJANJE UDESIMA - STUDIJA SLUČAJA PRAKSE VATROGASNO SPASILAČKIH BRIGADA}

Upravljanje rizikom od udesa u cilju obezbeđivanja bezbednosti radne i životne sredine uključuje veliki broj aktivnosti, mera i programa koje treba preduzeti pre, za vreme i posle udesa da bi se izbeglli, smanjio uticaj, i ublažili njihovi efekti, redom. Preduzeće ili drugo pravno lice je u obavezi da pripremi plan zaštite od udesa i da ga se pridržava kada se preduzimaju mere za sprečavanje udesa $i$ minimiziranje uticaja na život $i$ zdravlje ljudi, imovine $i$ životne sredine. Struktura takvog plana je predstavljen zajedno sa pravnim okvirom za upravljanje udesima.

Rad sadrži uvid u stavove članova vatrogasno spasilačkih brigada u vezi sa različitim aspektima vanrednih situacija u kontekstu upravljanja udesima u globalu. U studiji je učestvovalo ukupno 45 ispitanika. Nalazi pokazuju da gotovo svi ispitanici smatraju da su njihova znanja $i$ sposobnosti primenljiva u fazi intervencije kao i da manje od polovine veruju da su njihove sposobnosti primenljive u fazi prevencije, dok se dve trećine ispitanika izjasnilo da imaju podršku za dalje obrazovanje i usavršavanje u okviru njihovih organizacija.

Ključne reči: vanredne situacije, upravljanje rizikom, vatrogasac spasilac, prevencija udesa 